\title{
Corporate Criminal Liability: Toward a Compliance-Orientated Approach
}

Gustavo A. Jimenez

Indiana University Maurer School of Law, gajimene@indiana.edu

Follow this and additional works at: https://www.repository.law.indiana.edu/ijgls

Part of the Business Administration, Management, and Operations Commons, Business Law, Public Responsibility, and Ethics Commons, Business Organizations Law Commons, Comparative and Foreign Law Commons, and the International Trade Law Commons

\section{Recommended Citation}

Jimenez, Gustavo A. (2019) "Corporate Criminal Liability: Toward a Compliance-Orientated Approach," Indiana Journal of Global Legal Studies: Vol. 26 : Iss. 1 , Article 12.

Available at: https://www.repository.law.indiana.edu/ijgls/vol26/iss1/12

This Note is brought to you for free and open access by the Law School Journals at Digital Repository @ Maurer Law. It has been accepted for inclusion in Indiana Journal of Global Legal Studies by an authorized editor of Digital Repository@Maurer Law. For more information, please contactrvaughan@indiana.edu.

\section{$\Psi$}

JEROME HALL LAW LIBRARY

INDIANA UNIVERSITY

Maurer School of Law
Bloomington 


\title{
Corporate Criminal Liability:
}

\section{Toward a Compliance-Orientated Approach}

\author{
Gustavo A. JimenEZ
}

\begin{abstract}
Under U.S. federal law, a corporation can be held criminally liable for the crimes of its employees and agents. The Department of Justice's U.S. Attorneys' Manual lays out a list of factors prosecutors can evaluate when deciding whether or not to prosecute a corporate entity. The Department of Justice (DOJ) prosecutors have various tools at their disposal, including deferred prosecution agreements (DPAs) and non-prosecution agreements (NPAs) as alternatives to going to trial. Prosecutors have used DPAs and NPAs in recent cases, allowing the government to ensure that corporate entities comply with investigations, enact compliance programs, and continue to follow laws and regulations. The use of DPAs and NPAs are on the rise, and these agreements are now used in cases concerning the Foreign Corrupt Practices Act (FCPA) and the U.S. Commodity Future Trading Commission (CFTC). Comments from the Trump Administration suggest that these agreements will continue to be used to deter corporate criminal misconduct. Many Latin American countries have recently enacted laws to impose corporate criminal liability and use some type of compliance-based program to help deter future wrongdoing. Mexico, in particular, has recently amended its Federal Penal Code to prosecute and punish corporate entities. Since the Mexican case law in this area is still developing, it is very important that Mexico adopt deferred prosecution agreements, non-prosecution agreements, or a variation thereof that require compliance programs to enhance the public perception of the Mexican government and the judiciary. Mexico is just one of many countries amending its laws, suggesting a shift toward an implied

\footnotetext{
* Managing Editor, Indiana Journal of Global Legal Studies, Volume 26; J.D. Candidate 2019, Indiana University Maurer School of Law; B.A. 2014, University of California, San Diego. I am grateful to Professor Joseph L. Hoffmann for his guidance in the early stages of researching and writing this note. I would like to thank my parents, sister, and girlfriend for their unwavering support throughout law school.
}

Indiana Journal of Global Legal Studies Vol. 26 \#1 (Winter 2019)

(C) Indiana University Maurer School of Law 
understanding of the importance of a compliance-oriented approach. Foreign jurisdictions and the U.S. DOJ continue to enact programs to help regulate laws and deter criminal activity in many industries. The acceptance of the corporate criminal liability doctrine in several jurisdictions promotes the public interest and the integrity of the legal system, deters future illegal activity, and helps ensure corporate compliance with the law.

\section{INTRODUCTION}

The misdeeds of a corporation can lead to criminal liability. Corporate entities found to be engaged in wrongdoing can be sanctioned and punished under both civil and criminal law. The theory behind the doctrine of corporate criminal liability is that a corporation is considered a "person" that can only act through the actions of its employees. ${ }^{1}$ Various countries have addressed corporate criminal liability in a way that shows they too are moving toward accepting the doctrine and a compliance-oriented approach.

In this paper, I discuss how the United States and some Latin American countries address corporate criminal liability and propose my view on how deferred prosecution agreements (DPAs) and nonprosecution agreements (NPAs) serve an important function in creating effective compliance-based programs in the United States. By looking at various laws in foreign jurisdictions relating to corporate criminal liability, I propose there is a possible global convergence in the norms around the doctrine and that the shift toward compliance programs achieves one of the main purposes of criminal law-deterrence.

In Part II, I give a general overview of the corporate criminal liability doctrine in the United States, including a discussion of the U.S. Attorneys' Manual and the guidelines set out by the DOJ for prosecuting corporate entities. Part III discusses both DPAs and NPAs as tools prosecutors have at their disposal when prosecuting corporate entities, including a discussion of recent cases and the perception of these types of agreements. In Part IV, I give a general overview of corporate criminal liability in some Latin American countries, discuss how the doctrine has developed in these jurisdictions, and illustrate how these laws also show a shift toward a compliance-oriented approach for the laws in Latin American countries. Mexico, in particular, has just amended its anti-corruption laws, including reforms that now impose corporate criminal liability. In Part V, I examine the corporate criminal

1. See Andrew Weissmann \& David Newman, Rethinking Criminal Corporate Liability, 81 IND. L.J. 410, 412 (2007). 
liability doctrine, or variations of it, in foreign jurisdictions to propose that there is a possible global convergence around norms with respect to substantive issues that affect the corporate criminal liability doctrine. This convergence shows a shift toward a compliance-oriented approach that could help solve the problem of corporate entities' criminal actions in many industries and jurisdictions.

\section{CORPORATE CRIMINAL LIABILITY IN THE UNITED STATES}

\section{A. General Overview of the U.S. Federal Law}

Under the common law, a corporation could not be held criminally liable for the acts of its constituents. ${ }^{2}$ Under the common law, a corporation was not a person; therefore, it could not be held criminally liable. Following a series of Supreme Court decisions, the doctrine of corporate criminal liability became an accepted rule under the theory of civil vicarious liability. ${ }^{3}$ After the Supreme Court stated it saw no objection to the law for holding a corporation criminally liable for the transactions of its agents in New York Central \& Hudson River Railroad v. United States, federal courts accepted the idea of holding corporate entities criminally liable. ${ }^{4}$ One of these early cases was Dollar S.S. Co. v. United States in which a steamship corporation was convicted for violating a statute that barred dumping refuse in navigable waters. ${ }^{5}$ The Supreme Court stated that the steamship corporation was liable because its officers ultimately "failed to prevent the commission of the forbidden act." ${ }^{6}$ Corporate criminal liability continued to develop through judicial interpretation and the existing statutory law to become an accepted doctrine imposed to regulate a corporation's actions. ${ }^{7}$

Under current U.S. federal law, a corporation can be held criminally liable for the crimes its employees and agents commit in the corporation's interest. ${ }^{8}$ Corporate criminal liability can be imposed for regulatory offenses, economic offenses, and common law crimes. ${ }^{9}$ Corporate criminal liability is confined to the following offenses: those committed by "(a) the

2. See Dane C. Ball \& Daniel E. Bolia, Ending a Decade of Federal Prosecutorial Abuse in the Corporate Criminal Charging Decision, 9 WYO. L. REV. 230, 232 (2009).

3. See id. at 233-34; see also N. Y. Central \& Hudson River R.R. Co. v. United States, 212 U.S. 481 (1909).

4. See Weissmann \& Newman, supra note 1 , at 421.

5. See id.

6. Id.

7. See Corporate Criminal Liability Law and Legal Definition, USLEGAL (Nov. 2, 2018), https://definitions.uslegal.com/c/corporate-criminal-liability/.

8. See Charles doyle, Cong. Research Serv., R43293, Corporation Criminal LIABILITY: AN OVERVIEW OF FEDERAL LAW 1 (2013).

9. See id. 
corporation's officers, employees, or agents; (b) within the scope of their employment; and (c) at least in part for the benefit of the corporation." 10 Thus, under principles of respondeat superior, a corporation is vicariously criminally liable for the illegal acts of its employees. ${ }^{11}$ The test to determine the scope of authority is whether an individual is (1) performing acts within his or her general line of work and (2) if the acts are motivated at least in part with in the intent to benefit the corporation. ${ }^{12}$

The Model Penal Code, on the other hand, imposes corporate criminal liability for the acts and misconduct of a corporation's senior management officials (the acts of lower level employees will not always be enough). ${ }^{13}$ Some states have chosen not to follow the federal approach and have opted for an approach similar to the Model Penal Code's approach. ${ }^{14}$

The DOJ decides whether to prosecute a corporation, its employees, or both for their criminal acts. ${ }^{15}$ The DOJ has two sets of guidelines that govern the decision on whether to prosecute: the Principles of Federal Prosecution and the Principles of Federal Prosecution of Business Organizations. ${ }^{16}$ The DOJ aims to promote the public interest, deter future illegal acts, ensure corporate compliance with the law, and promote the integrity of our legal system ${ }^{17}$ by holding both corporate

10. Id. at 3 .

11. See Clifford Chance, Corporate Criminal liability 10 (2016), https://www.cliffordchance.com/briefings/2016/04/corporate_criminalliability.html.

12. See DoYLE, supra note 8, at 3; see also United States v. Agosto-Vega, 617 F.3d 541, 552-53 (1st Cir. 2010) ("Typically, [t]he test is whether the agent is performing acts of the kind which he is authorized to perform, and those acts are motivated -. at least in part .by an intent to benefit the corporation." (quoting United States v. Potter 463 F.3d. 9, 25 (1st Cir. 2006)) (internal quotation marks omitted).

13. See DoYle, supra note 8, at 3-4; see also MOdel PenAL Code $\$ 2.07$ (AM. L. InST. 1985) ("A corporation may be convicted of the commission of an offense if (a) the offense is a violation . . . in which a legislative purpose to impose liability on corporations plainly appears and the conduct is performed by an agent of the corporation acting in behalf of the corporation within the scope of his office or employment ... (b) the offense consists of an omission to discharge a specific duty or affirmative performance imposed on corporation by law; or (c) the commission of the offense was authorized, requested, commanded, performed or recklessly tolerated by the board of directors or by a high managerial agent acting in behalf of the corporation within the scope of his office or employment. (2) When absolute liability is imposed for the commission of an offense, a legislative purpose to impose liability on a corporation shall be assumed, unless the contrary plainly appears...").

14. See Weissmann \& Newman, supra note 1 , at 423 .

15. See DOYLE, supra note 8 , at 8.

16. United States AtTorneys' MANUAL $\$ \$ 9-27.000-28.000$ (U.S. DeP’t of JUST. 2018), available at https:/www.justice.gov/usam/title-9-criminal; see also $\$ 9-28.200 \mathrm{n}$. 1 ("While these guidelines refer to corporations, they apply to the consideration of the prosecution of all types of business organizations, including partnerships, sole proprietorships, government entities, and unincorporated associations.").

17. See USAM, supra note 16 , at $\S 9-28.010$. 
entities and individuals who engage in wrongdoing criminally liable.

\section{B. Factors to be Considered and the DOJ Guidelines}

There are several factors that prosecutors consider when deciding whether to prosecute a corporation. ${ }^{18}$ The factors are similar to those prosecutors consider when deciding whether to prosecute an individual. ${ }^{19}$ Prosecutors also look into the seriousness of the offense committed and the culpability of the defendants. ${ }^{20}$ The factors prosecutors weigh include: $:^{21}$

1. the nature and seriousness of the offense; ${ }^{22}$

2. the pervasiveness of the corporation's wrongdoing; 23

3. any history of the corporation engaging in similar misconduct; ${ }^{24}$

4. the corporation's willingness to cooperate in investigations and timely disclosures of wrongdoing; ${ }^{25}$

5. the existence and effectiveness of a corporation's compliance program, including efforts to implement or improve an existing one; ${ }^{26}$

6. collateral consequences; ${ }^{27}$ and

7. the adequacy of remedies. ${ }^{28}$

The Principles of Federal Prosecution of Business Organizations is very clear as to the amount of discretion prosecutors are afforded in making their determination. ${ }^{29}$ Under each of the factors, there are considerations a prosecutor can take into account. For instance, when looking at the nature and seriousness of the crime, there are policy concerns, including the consequences and harm from the company's wrongful actions. ${ }^{30}$ Prosecutors will look into the policy goals and

18. See id. at $\$ 9-28.300$.

19. See id. "The sufficiency of the evidence; the likelihood of success at trial; the probable deterrent, rehabilitative, and other consequences of conviction.")

20. See DoYLE, supra note 8 , at 8 .

21. See USAM, supra note 16 , at $\$ 9-28.000$ (the factors are illustrative and do not represent an exhaustive list of factors that a prosecutor can find relevant under her or her discretion).

22. See id. at $\$ 9-28.400$.

23. See id. at $\$ 9-28.500$.

24. See id. at $\$ 9-28.600$.

25. See id. at $\$ 9-28.700, \S 9-28.900$.

26. See id. at $\$ 9-28.800, \S 9-28.1000$.

27. See id. at $\$ 9-28.1100$.

28. See id. at $\$ 9-28.1200,9-28.1300$.

29. For a detailed explanation of the guidelines, see id. at $\$ 9-28.00$.

30. See id. at $\$ 9-28.400[\mathrm{~B}]$. 
incentive programs set up by regulatory agencies when assessing this factor. ${ }^{31}$

When prosecutors examine the pervasiveness of wrongdoing, a critical factor is the role and conduct of management, their degree of responsibility, and their authority. ${ }^{32}$ Prosecutors will examine the number of employees engaged in the misconduct or if the misconduct was contained to a small number of upper management personnel to determine if it is appropriate to impose corporate liability. ${ }^{33}$

When prosecutors review the company's past criminal conduct, any past civil or regulatory enforcement actions can be taken into account. ${ }^{34}$ The fact that a company has a compliance program in place does not absolve it from criminal liability. Prosecutors can evaluate the effectiveness of this plan in detecting and reducing wrongful acts as well as whether the compliance program merely exists on paper without actually being implemented. ${ }^{35}$ When prosecutors look at the collateral consequences, they may take into account possible substantial consequences to a corporation's employees, investors, pensioners, and customers, and the role those individuals had in the criminal wrongdoing, if any. 36

According to the DOJ Prosecutorial Guidelines, once a prosecutor decides to charge a corporation, the prosecutor should charge the corporation with the most serious offense consistent with the nature of the defendant's criminal acts that is likely to result in a conviction. ${ }^{37}$

It is important to note that the Guidelines are not legally binding and do not have the force of the law behind them-they are strictly guidelines. ${ }^{38}$

Once a prosecutor decides to prosecute a corporate entity, there are various alternatives to trial that the prosecutor can take. For instance, a corporation can plead guilty and seek a plea to the alleged offense. ${ }^{39}$ Some of the other alternatives include: deferring prosecution under a

31. See id.

32. See id. at $\$ 9-28.500[\mathrm{~B}]$.

33. See id. at $\$ 9-28.500[\mathrm{~A}]$.

34. DOYLE, supra note 8 , at $9-10$.

35. See USAM, supra note 16 , at $\$ 9-28.800[\mathrm{~B}]$. ("[T]he critical factors in evaluating any program are whether the program is adequately designed for maximum effectiveness in preventing and detecting wrongdoing by employees and whether corporate management is enforcing the program or is tacitly encouraging or pressuring employees to engage in misconduct to achieve business objectives").

36. See id. at $\$ 9-28.1100[\mathrm{~B}]$.

37. See id. at $\$ 9-28.1400$.

38. See Ball \& Bolia, supra note 2, at 259 (They provide the Department of Justice with guidance and "are not intended to, do not, and may not be relied upon to create any rights, substantive or procedural enforceable at law by any party in a manner civil or criminal.").

39. DOYLE, supra note 8 , at 11 ; see also, USAM, supra note 16 , at $\$ 9-28.1500$. 
DPA; accepting a corporation's offer to sign a NPA with the intent to prosecute corporate officials and/or employees; or foregoing criminal prosecution while agreeing to civil sanctions (when criminal misconduct occurs in the regulatory context). ${ }^{40}$

\section{Deferred Prosecution Agreements and Non-Prosecution AGREEMENTS}

\section{A. General Overview}

A deferred prosecution agreement (DPA) is filed in court and privately negotiated. ${ }^{41}$ The Department of Justice (DOJ) agrees to defer prosecution in exchange for the company's acknowledgment of responsibility for the alleged conduct while agreeing to take complianceoriented actions. ${ }^{42}$ Some of the terms that DPAs include are:

(1) An acknowledgement of responsibility for the conduct; (2) an acknowledgement that if the defendant commits similar conduct during the pendency of the agreement that the Government may prosecute for any crime including the subject matter of the agreement; (3) an obligation to cooperate with the Government's continuing investigation including making current employees available for testimony; (4) waiver of the defendant's right to a speedy trial and defenses created by any relevant statute of limitations; (5) language that prohibits the defendant from making contradictory factual representations as those found in the agreement; and (6) the imposition of penalties, fines, restitution and other remedial relief (emphasis added). ${ }^{43}$

Non-prosecution agreements (NPAs) are negotiated between the DOJ and the corporate entity. NPAs are less detailed than DPAs. ${ }^{44}$ While there are no formal filing charges under a NPA, the DOJ and corporate defendant enter into an agreement that takes the form of a

40. See Doyle, supra note 8, at 11.

41. See id. at 12

42. Mike Koehler, Measuring the Impact of Non-Prosecution and Deferred Prosecution Agreements on Foreign Corrupt Practices Act Enforcement, 49 U.C. DAVIS L. REV. 497, 505 (2015).

43. Stephen L. Hill, Jr. \& Emma Radmore, Deferred Prosecution Agreements: The US Experience and the UK Potential, LEXOLOGY (July 14, 2014), https://www.lexology.com/library/detail.aspx?g=4f0cc529-bfdb-49c3-ac8d-e989e87fc84a.

44. See Koehler, supra note 42 , at 505 . 
letter wherein the corporation agrees to cooperate with the government and take remedial actions necessary to correct the wrongdoing. ${ }^{45}$

One of the reasons a corporate entity may elect to choose a DPA or a NPA is that an indictment to the corporation threatens to put it out of business. ${ }^{46}$ For example, in 2002, Arthur Anderson, one of the top accounting firms in the world, was indicted and ultimately convicted for obstruction of justice for destroying evidence in relation to the Enron scandal. ${ }^{47}$ The decision was overturned by the Supreme Court but not before the collapse of the $\$ 9.3$ billion corporation with over 85,000 employees worldwide. ${ }^{48}$ From Arthur Anderson's collapse, many companies now fear that a conviction would be a threat to their existence, creating a strong incentive to choose to elect either a deferred prosecution agreement or a non-prosecution agreement.

The increase in the use of DPAs and NPAs is in line with the founding principles of corporate prosecution, as laid out in the U.S. Attorney's Manual. ${ }^{49}$ Because these agreements contain provisions for the company to cooperate with the government's ongoing investigations and the implementation of compliance programs, DPAs and NPAs achieve one of the main purposes of criminal law-deterrence. ${ }^{50}$

45. See Lawrence E. Ritchie et al, DOJ Enters into Non-Prosecution Agreement with Las Vegas Sands Corporations Over Alleged FCPA Violations, OSLER (Feb 3, 2017), https//www.osler.com/en/blogs/risk/february-2017/doj-enters-into-non-prosecution-agreementwith-las. For a sample of a non-prosecution agreement see, https:/www.justice.gov/ opa/file/868771/download.

46. See DOYLE, supra note 8 , at 12 .

47. See Len Lyons \& Audra Marino, Deferred Prosecution Agreements, Non-Prosecution Agreements and Monitoring Services, MARCUM LLP (Aug. 2012), http://www.marcumllp.com/insights-news/deferred-prosecution-agreements-nonprosecution-agreements-and-monitoring-services; see also Arthur Anderson Indicted in Enron Case, ABC NEws (March 2014), http://abcnews.go.com/Business/story?id=87293 \&page=1; see generally Richard A. Oppel Jr. \& Kurt Eichenwald, Enron's Collapse: The Overview; Arthur Anderson Fires an Executive for Enron Orders, N.Y. TIMEs (Jan. 16, 2002), http://www.nytimes.com/2002/01/16/business/enron-s-collapse-overview-arthurandersen-fires-executive-for-enron-orders.html (providing an overview of the Enron case).

48. See Lyons \& Marino, supra note 47

49. See USAM, supra note 16 , at $\$ 9-28.100$ ("These interests include, among other things: (1) protecting the integrity of our economic and capital markets by enforcing the rule of law; (2) protecting consumers, investors, and business entities against competitors who gain unfair advantage by violating the law; (3) preventing violations of environmental laws; and (4) discouraging business practices that would permit or promote unlawful conduct at the expense of the public interest").

50. See Bruce Coleman, Is Corporate Criminal Liability Really Necessary, 29 SMU L. Rev. 908, 925 (1975). 


\section{Non-Prosecution Agreement Cases}

NPAs encourage deterrence of a company's wrongdoing by providing law enforcement with the ability to impose mandates on companies that will change their behavior, force the corporate entities to cooperate with the law enforcement investigations, and require the corporate entity to improve their compliance programs. ${ }^{51}$

A case to illustrate this point is the NPA reached after the death of twenty-nine miners at the Massey Energy Upper Big Branch (Massey) mine near Montcoal, West Virginia. An explosion resulting from the ignition of the accumulation of methane from the lack of proper safety protocols killed the miners. ${ }^{2}$ Massey was aware of its poor safety methods and environmental record, including its concealment of safety violations from the Mine Safety and Health Administration (MSHA). ${ }^{53}$ Massey intimidated workers to keep them from reporting violations and kept two sets of books-one with the violations that the company was aware of and one it presented to safety inspectors that omitted the known violations. ${ }^{54}$ The DOJ indicted Massey's head of security "for lying about the practice of giving advance notice of inspections [to its employees] and attempting to destroy evidence". ${ }^{55}$ The DOJ charged several of the upper management personnel, ${ }^{56}$ which showed that even if there were no formal charges filed against the corporation, the heads of the company would not escape prosecution for voluntarily disregarding regulatory procedures.

The DOJ announced that it was entering into a NPA with Massey and would not bring criminal charges against the company. The DOJ justified its decision on the fact that the company had agreed to implement compliance programs. ${ }^{57}$ While critics can argue that the lack of a guilty plea or admission of liability did not allow justice to be served where a corporation failed to follow regulations, the consequences of the NPA allowed the government to require Massey to undertake compliance efforts. In addition, these agreements are often made public, which sends a message to other companies about the consequences they may face if they also willfully disregard existing laws and regulations.

Another example in which the DOJ entered into a NPA involves the

51. See Ritchie et al., supra note 45.

52. See David M. Uhlmann, Deferred Prosecution and Non-Prosecution Agreements and the Erosion of Corporate Criminal Liability, $72 \mathrm{MD}$. L. REV. 1295, 1295 (2013).

53. See id. at 1296 .

54. See id. at 1297 .

55. See id. at 1298 .

56. See id.

57. See id at 1300 . 
Las Vegas Sands Corporation (Las Vegas Sands). 58 Under the NPA, the company agreed to pay a criminal penalty of almost $\$ 7$ million after admitting that many of its management and executive personnel knew they had failed to implement a legitimate system of internal accounting controls. ${ }^{59}$ Las Vegas Sands admitted to "ignoring warnings from its financial staff and an outside auditor about the payments, and fired the employee who raised concerns about the payments." 60 This case shows how a NPA still allows a company to acknowledge its responsibility in the criminal misconduct and requires the company to pay fines for its actions. Thus, despite no formal charges being filed in court, the corporate entity is not completely absolved from its wrongdoing.

\section{Deferred Prosecution Agreement Cases}

The policy consideration behind DPAs is simple: companies are to comply with the provisions laid out in the agreements, and if the conditions set forth are not met to the satisfaction of the government, the DOJ will take action.

For example, in 2012, Zimmer Biomet, a medical device company, reached a DPA with the DOJ in which it agreed to pay over $\$ 22$ million in penalties, implement internal controls, and retain a compliance monitor for a period of eighteen months. ${ }^{61}$ In June 2017, the company violated its DPA for failing to maintain its compliance program by failing to monitor internal controls in its activity overseas and is now facing criminal prosecution. ${ }^{62}$ This is one instance demonstrating that the DOJ will not let companies escape prosecution should they not uphold their part of the agreement.

The DOJ also entered into DPAs with two corporations earlier this year. On January 18, 2018, HSBC Holdings PLC (HSBC) entered into a DPA with the DOJ Fraud Section regarding two counts of alleged wire fraud. ${ }^{63}$ The DOJ considered several factors in reaching a resolution and ultimately imposed a $\$ 63.1$ million penalty on the corporation to be paid

58. See Ritchie et al., supra note 45.

59. See id.

60. See id

61. See Amirah Al Idrus, Zimmer Biomet Broke Deferred Prosecution Agreement with DOJ: Reuters, FIERCEBIOTECH (June 15, 2016, 11:42 AM), http://www.fiercebiotech.com /medical-devices/zimmer-biomet-broke-deferred-prosecution-agreement-doj-reuters.

62. See id.

63. See F. Joseph Warin et al., 2018 Mid-Year Update on Corporate Non-Prosecution Agreements (NPAs) and

Deferred Prosecution Agreements (DPAs), GiBson DUNN (July 10, 2018), https:/Www.gibsondunn.com/2018-mid-year-npa-dpa-update/. 
to the U.S. Treasury. ${ }^{64}$ On February 12, 2018, U.S. Bancorp (USB) also entered into a DPA with the U.S. Attorney's Office for the Southern District of New York for criminal charges for "failing to maintain an adequate anti-money laundering program and willfully failing to file a Suspicious Activity Report." 65 As part of the DPA, USB was fined for $\$ 528$ million. ${ }^{66}$ These cases are some examples of how DPAs can induce monetary resolutions.

\section{B. The Use of DPAs and NPAs}

A corporation, by its nature, cannot be put away in the same way one would lock away an individual. However, DPAs and NPAs give prosecutors effective tools to deter companies by shifting the focus from acts of misconduct to a compliance-oriented approach. Corporations and their management are not let off the hook that easily.

These agreements protect consumers, investors, and business entities against competitors who gain an unfair advantage by violating the law by subjecting them to penalties and sanctions. This was certainly the case for Las Vegas Sands, which ended up paying $\$ 6.96$ million and agreed to continued cooperation with the DOJ. ${ }^{67}$ In another case, State Street Corporation agreed to pay $\$ 32.3$ million in criminal penalties when it entered into a DPA as a result of its fraud schemes aimed at charging clients unwarranted commissions. ${ }^{68}$ According to Acting Assistant Attorney General David Bitokwer, "the bank fundamentally abused its clients' trust and inflicted very real financial losses." ${ }^{2}$ The message these agreements send to other companies is clear-the DOJ will not just come after the company and let the guilty individuals avoid responsibility.

These agreements also pressure upper management personnel to ensure they implement policies that are in line with regulations, not only because their jobs and careers may be on the line, but also because they may face criminal prosecution. For example, the DOJ reached a DPA with the accounting firm KPMG for participating in a scheme attempting to defraud the IRS by "devising, marketing, and

64. See id.

65. Id.

66. See id.

67. See Ritchie et al., supra note 45.

68. See Office of Public Affairs, State Street Corporation Agrees to Pay More than \$64 Million to Resolve Fraud Charges, DEP'T OF JUST. (Jan. 18, 2017), https://www.justice.gov/opa/pr/statestreet-corporation-agrees-pay-more-64-million-resolve-fraud-charges.

69. Id. 
implementing fraudulent tax shelters." 70 The company's former deputy chairman and many of its officials were prosecuted and indicted, and the company paid $\$ 456$ million in fines. ${ }^{71}$

In a different case, Sheffield Pharmaceutical's former president and chief executive officer were charged with a felony for violating the Clean Water Act by "discharging polluted industrial wastewater from its New London Factory into the municipal sewage system without the required permit and industrial wastewater treatment system." 72 The former president and chief executive officer pled guilty and received three years of probation, a $\$ 30,000$ fine, and community service. ${ }^{73}$ The court ordered Sheffield Pharmaceutical to pay $\$ 1$ million and comply with all the environmental laws and regulations as part of the DPA. ${ }^{74}$

As illustrated with the cases above, under these agreements, prosecutors can ensure that if the management of a corporation doesn't comply with regulations, they will not be able to escape prosecution by pinning the blame on the corporation itself, nor will they be able to keep their respective positions and be subjected to fines. The use of DPAs and NPAs further illustrate the deterrence mechanism on corporations and their management.

\section{DPA and NPA with respect to the FCPA}

There are certain situations in which it has been argued that the frequent use of DPAs and NPAs basically prevents the courts from resolving serious issues about the appropriate scope of a criminal statute. One of those situations is with respect to the DOJ's enforcement of the Foreign Corrupt Practices Act (FCPA). The FCPA was "enacted for the purposes of making it unlawful for certain classes of people and entities to make payments to foreign government officials to assist in obtaining or retaining business." 75 The anti-bribery provisions of the FCPA apply to all U.S. persons, foreign firms, and persons who, directly or through their agents, act in furtherance of a corrupt payment within

70. Terry Frieden, Justice Department Indicts Eight Ex-KPMG Execs: Firms Agrees to Pay \$456 Million Fine, CNN.COM INTERNATIONAL (Aug. 29, 2005, 11:34 PM), http://edition.cnn.com/2005/POLITICS/08/29/kpmg.justice/.

71. See id

72. U.S. Envtl. Prot. Agency Off. of Crim. EnF't, Forensics and Training, Environmental Crimes CASE Bulletin 8, (2016) https:/www.epa.gov/sites/ production/files/201701/documents/december_2016_enviro_crimes_case_bulletin.pdf.

73. See id.

74. See id

75. Foreign Corrupt Practices Act, The United States DeP'T OF Just. (Feb. 3, 2017), https://www.justice.gov/criminal-fraud/foreign-corrupt-practices-act. 
U.S. territory. ${ }^{76}$

Enforcement actions brought under the FCPA have been expanding, but the legal realm is a "legal desert" due to the lack of binding case law. ${ }^{77}$ There is no concrete guidance as to many of the ambiguities surrounding the statutory language of the FCPA. ${ }^{78}$ One of the main reasons for the lack of legal binding precedent is because DPAs and NPAs have kept cases away from court and prevented corporations from dealing with the consequences of a guilty conviction. ${ }^{79}$ Instead, many FCPA cases are resolved through settlements. ${ }^{80}$

There are a few possible explanations for why the use of DPAs and NPAs will likely continue to increase in FCPA actions in the coming years. One is the fact that FCPA violations require some activity to occur outside of U.S. territory, meaning that there would likely be increases in the costs of investigations of violations in more than one jurisdiction. ${ }^{81}$ Thus, corporations may elect to pay fines to the DOJ and its foreign counterparts as part of a settlement and resolve the matter. For instance, the corporation Siemens ultimately paid millions in fines to the DOJ to settle charges and will also be paying $\$ 569$ million to the Office of the Prosecutor General in Munich for bribes in other transactions worldwide. ${ }^{82}$

Another consideration for the increase in the use of DPAs and NPAs in FCPA cases is the fact that FCPA cases might have greater negative reputational consequences to corporations than generic white collar crimes. ${ }^{83}$ Attorney General Jeff Sessions laid out an important consideration for law enforcement of the FCPA. He stated that corruption increases the cost of doing business, and proper enforcement protects honest companies from competitors who pay bribes to try to get ahead. ${ }^{84}$ With heavy enforcement in this area, it is very possible that the case law surrounding FCPA violations will remain undeveloped and continue to draw guidance from enforcement actions and settlements if

76. See id.

77. Nick Gersh, The Curious Absence of FCPA Trials, GAB: THE GLOBAL ANTICORRUPTION BLOG (Sept. 8, 2017), https://globalanticorruptionblog.com/tag/nonprosecution-agreements/.

78. See id.

79. See id.

80. See id.

81. See id.

82. See SEC Charges Siemens AG for Engaging in Worldwide Bribery, U.S. SEC. \& EXCHANGE COMMISSION (Dec. 15, 2008), https:/www.sec.gov/news/press/2008/2008294.htm.

83. See Gersh, supra note 77.

84. See Richard L. Cassin, $A G$ Sessions: 'We Will Continue to Strongly Enforce the FCPA', FCPA BLOG (Apr. 25, 2017, 7:18 AM), http://www.fcpablog.com/blog/2017/4/25/agsessions-we-will-continue-to-strongly-enforce-the-fcpa.html. 
the courts are kept from establishing binding legal precedent.

\section{Are DPAs and NPAs here to Stay?}

As of July 2018, the DOJ has entered into six NPAs and six DPAs for a total of twelve agreements. ${ }^{85}$ This six-month period should not be taken to show any trend, as the DOJ entered into 102 of these agreements in 2015, and then dropped to thirty-nine agreements in $2016 .{ }^{86}$ In 2017, the total number of agreements was twenty-two, and at the six-month period the number of agreements was only ten. ${ }^{87}$ This suggests that there might be an increase in the number of agreements that are entered into this year.

Chart 1: Corporate NPAs and DPAs, 2000-2018 YTD

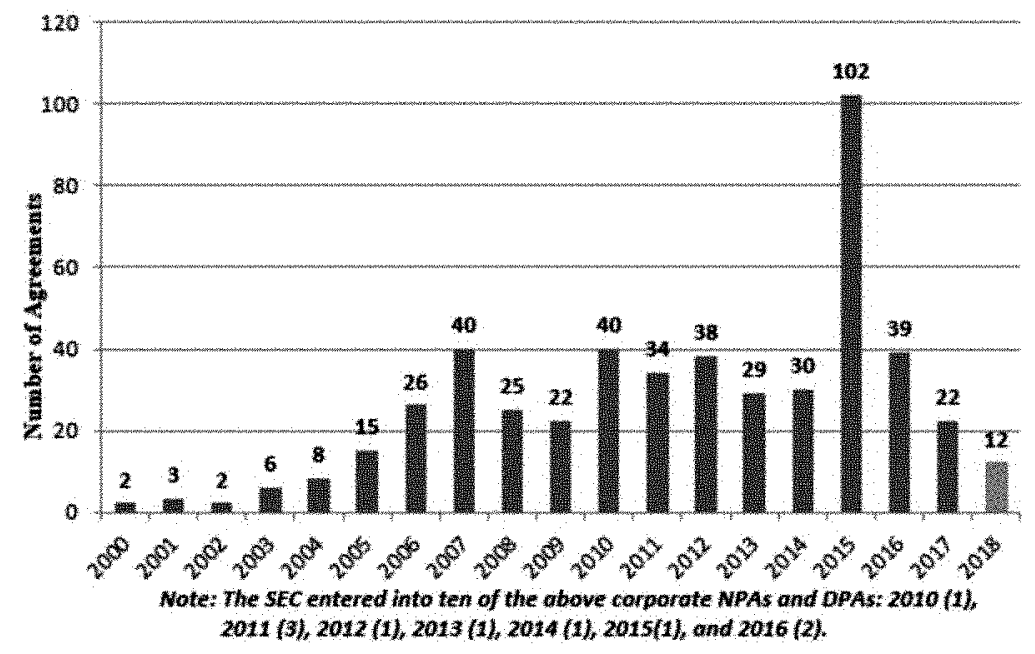

Source: Gibson, Dunn \& Crutcher LLP. The chart shows all known corporate NPAs and DPAs since 2000.

It certainly seems that the current administration will continue to use DPAs and NPAs. It would not be surprising if the number of agreements in 2018 is larger than the number of agreements in 2017.

85. Id. at 1 .

86. See id. at 2 .

87. See F. Joseph Warin et al., 2017 Mid-Year Update on Corporate Non-Prosecution Agreements (NPAs) and Deferred Prosecution Agreements (DPAs), GIBSON DunN (July 11, 2017), https://www.gibsondunn.com/2017-mid-year-update-on-corporate-non-prosecutionagreements-npas-and-deferred-prosecution-agreements-dpas/. 
Recent speeches from both Attorney General Sessions ${ }^{88}$ and Deputy Attorney General Rod Rosenstein seem to suggest that they will continue to take a tough but fair stance on the prosecution of both corporate entities and white collar crimes. ${ }^{89}$

During the Ethics and Compliance Initiative Annual Conference on April 24, 2017, Attorney General Sessions focused on the importance of compliance and stated that when the DOJ makes charging decisions, the DOJ will take into account the corporation's cooperation in government investigations and its compliance programs. ${ }^{90}$ Attorney General Sessions referred to the NPAs and the DPAs as tools at the DOJ's disposal, suggesting that these agreements will continue to be used in an effort to have companies create good compliance programs.

On May 9, 2018, Deputy Attorney General Rod Rosenstein announced a new policy imposing penalties on corporations at the New York City Bar White Collar Crime Institute. ${ }^{91}$ The DOJ's recent amendments discourage the "piling on" of penalties relating to the same misconduct, which results from the lack of coordination among enforcement agencies when imposing such penalties. ${ }^{92}$ This new policy comes with four features in an effort to "discourage disproportionate enforcement of laws by multiple authorities," to provide certainty and finality of penalties that are imposed on a corporation, and to encourage a fair and just result when resolving a case using a DPA or NPA. ${ }^{93}$

These comments suggest that the DOJ will continue to pursue corporations for any wrongdoings, use corporate compliance programs as a deterrent, and properly coordinate agencies in order to reach equitable results.

\section{Corporate Criminal Prosecution in Latin America}

\section{A. Corporate Criminal Liability in Brazil, Argentina, and Chile}

With the future pointing to the continued use of corporate nonprosecution agreements (NPA) and deferred prosecution agreements (DPA) in the United States, many Latin American countries' enactment

88. See id.

89. See id.; Warin et al., supra note 63 , at 3.

90. See Attorney Gen. Jeff Sessions, Remarks at the Ethics and Compliance Initiative Annual Conference (Apr. 24, 2017) transcript available at https:/www.justice.gov/ opa/speech/attorney-general-jeff-sessions-delivers-remarks-ethics-and-complianceinitiative-annual.

91. See Warin et al., supra note 88.

92. Warin et al., supra note 63 , at 3 .

93. Id. 
of corporate criminal liability doctrines show the importance of the doctrine abroad. I will examine four countries in Latin America that have enacted laws holding corporations liable in various industries to demonstrate a trend toward compliance through cooperation with governments and authorities.

In Brazil, the Brazilian Clean Companies Act ((Law No. 12,846) took effect on January 29, 2014 to hold a corporation liable for the corrupt actions of its employees. ${ }^{94}$ The act is an anti-bribery statute that sends a clear signal to companies in Brazil that the Brazilian government is cracking down on corruption. ${ }^{95}$ Any company that violates this act can be sanctioned up to $\$ 27$ million but can mitigate their fines if they cooperate with Brazilian authorities and implement effective compliance programs in accordance with the act. ${ }^{96}$

On November 8, 2017, the Argentine Congress approved a law establishing corporate criminal liability for crimes against public administration and international bribery. ${ }^{97}$ Some of the features of the law include holding private legal entities liable, holding entities liable when crimes are committed for a benefit, and holding successors liable. ${ }^{98}$ When a corporate entity violates the law they can be punished up to two to five times the benefit they obtained, fully or partially suspended for up to ten years, liquidated, forced to forfeit any goods or assets obtained during the violation, and barred from entering into public contracts. ${ }^{99}$

94. See Gabriela Roitburd, Preparing to Comply with Brazil's Clean Companies Act, Association of Corporate Counsel, https:/www.acc.com/accdocket/onlineexclusives/brazilcca.cfm (last visited Nov. 9, 2018). Brazil Compliance Guide, GAN BUS. ANTI-CORRUPTION PORTAL: COMPLIANCE GUIDES (Nov. 2015), http://www.business-anti-corruption.com/ compliance-quick-guides/brazil.

95. See id.; See also Renata Muzzi Gomes de Almeida \& Shin Jae Kim, The New Brazilian Clean Company Act, EMPEA: LEGAL \& REG. Bull. 2 (2014), https://Www.empea.org/app/uploads/2017/03/Brazilian-Clean-Company-Act.pdf. The full text of the act can be accessed here: https:/Www.cov.com/files/upload/EAlert_Attachment_Brazilian_Clean_Companies_Act_Original.pdf (discussing how the act has encouraged the implementation of inti-corruption controls).

96. See Gomes de Almeida \& Kim, supra note 96, at 1-2.

97. Maria Lorena Schiariti, Juan Manuel Naveira \& Agustina Guazzaroni, Corporate Criminal Liability Regime, MARvaL O'FARRELl MAIRAL (Nov. 30, 2017), https://www.marval.com/publicacion/responsabilidad-penal-para-las-personas-juridicaspor-delitos-de-corrupcion-13091\&lang=en.

98. See id.

99. See id,; see also Fernando Goldaracena \& Vanina Caniza, Argentina: New Law of Corporate Criminal Liability Approved, Global Compliance News, (Mar. 12, 2018), https://globalcompliancenews.com/argentina-corporate-criminal-liability-20180312/ (discussing the penalties provided by the Corporate Criminal Liability Law); Clara Hudson, Argentina Introduces Corporate Criminal Liability, GLOBAL INVESTIGATIONS REV. (Nov. 13, 2017), https:/globalinvestigationsreview.com/article/1150080/argentina- 
The new Argentine law provides several exemptions from penalties that are in accordance with the trend toward having corporations implement effective compliance programs. One way is through an Integrity Program, a type of compliance program "consisting of actions, mechanisms, and internal proceedings for the promotion of integrity, supervision and control, focused on the prevention, detection, and correction of irregularities and unlawful acts." 100 "There are minimum requirements of the Integrity Program and other elements that require corporate entities to establish a code of ethics that lays out proper policies and procedures for management. ${ }^{101}$ Furthermore, the Argentine law allows for a corporate legal entity to enter into an Effective Collaboration Agreement, whereby the entity's penalties are reduced if they agree to cooperate by providing facts to the authorities to identify perpetrators, recovering assets, and complying with conditions set forth in the agreement. 102 These programs allow the government to regulate and deter corporate criminal wrongdoings by incentivizing corporate entities to enact adequate compliance programs to reduce its penalties.

In Chile, under the Corporate Criminal Liability Law (Ley 20392), corporate entities may be subject to criminal prosecution as a consequence of bribery committed by their agents. ${ }^{103}$ The theory behind the Chilean law is to penalize a company for failing to implement and fulfill its obligations of preventing the crime for which a corporation is accused. ${ }^{104}$ When enforcing actions against corporate entities, penalties and fines can be up to approximately $\$ 685,000$. 105 The Chilean law explicitly provides credit for corporate compliance programs; 106 this means Chile is another country that follows a compliance-oriented approach.

The Chilean law's leniency agreements resemble the DOJ's DPAs and NPAs. Under these agreements, Chilean law provides for the conditional suspensions of proceedings that can occur during

introduces-corporate-criminal-liability-law (discussing the penalties provided by the Corporate Criminal Liability Law).

100. Schiariti, et al., supra note 98 .

101. See Mario Eduardo Castro Sammartino, Corporate Criminal Liability in Argentina: A Short Term to Establish a Proper Compliance Program, CASTRO SAMMARTINO \& PIERINI (Dec. 15, 2017), http:/cspabogados.com ar/en/corporate-criminal-liability-in-argentina/. 102. Schiariti, et al., supra note 98 .

103. See Matteson Ellis, Anti-Corruption Laws in Chile: Three Things Companies Should Know, FCPAMERICAS (Dec. 19, 2013), http://fcpamericas.com/english/anticorruption-compliance/anti-corruption-laws-chile-companies/.

104. See Daniel Praetorius \& Jorge Bofill, Anti-Corruption 2017: Chile, LATIN LAw., http://atinlawyer.com/jurisdiction/1003067/chile (last verified June 8, 2017).

105. Id.

106. Ellis, supra note 104. 
investigations. $107 \mathrm{~A}$ settlement is made between prosecutors and defendants that determines the conditions that must be met within a defined period for a defendant to be acquitted. ${ }^{108}$ Similar to conditions set out in DPAs, the conditions or requirements can include the adoption of a compliance program or an obligation to make restitution payments. 109

A case example occurred in April 2013 when Chilean authorities secured a $\$ 2.5$ million settlement with Industrias Ceresita for alleged bribery payments to public officials in connection with construction permits. ${ }^{110}$ As part of the settlement, the corporate entity had to adhere to numerous conditions, including making major infrastructure improvements in the affected municipality, such as repainting buildings in the town's main square. ${ }^{111}$ The Chilean leniency agreements follow the compliance-oriented approach by punishing corporations when they violate government-set conditions, but also allowing restitution when the corporations cooperate.

\section{B. Corporate Criminal Liability in Mexico}

The implementation of the National Code of Penal Procedures and reforms made to the Federal Penal Code in Mexico in June 2016 has made it so that corporate entities can be prosecuted for criminal acts. ${ }^{112}$ Similar to the corporate criminal liability laws in other Latin American countries, corporate entities in Mexico can mitigate any criminal liability and sanctions imposed on them by showing that authorized individuals have taken measures to prevent ongoing, or future, criminal conduct. ${ }^{113}$ Under Article 11bis of the Mexican Federal Penal Code, ${ }^{114}$ a

\footnotetext{
107. $I d$.

108. Id.

109. See id.

110. See id.

111. See id.

112. Eduardo Parroquín Patiño, Criminal Liability of Entities, LEXOLOGY (July 20, 2017), https:/www.lexology.com/library/detail.aspx?g=a8ca927f-c7ba-4c59-93f3$0 \mathrm{a} 6 \mathrm{~b} 3 \mathrm{dc} 155 \mathrm{~d} 9$.

113. See id.

114. Org. for Econ. Co-Operation \& Dev., Corporate Liability for Corruption Offences in Latin America, OAS 2, 14, http://www.oas.org/juridico/pdfs/enc_compilation.pdf (last visited Sept. 7, 2018) (“ $[w]$ hen a member or a representative of a legal entity, partnership, corporation or company of any kind, except the institutions of the State, commit a crime using the means that said entities provide him/her for that purpose, in a way that the crime be committed in the name of, or under the protection the entity or for its benefit, the Court shall have the authority, under the cases exclusively specified by the law, to order within the sentence the suspension or the dissolution of the entity if he deem it necessary for the sake of public security.").
} 
corporate entity may be punished for crimes including tax fraud, narcotics trafficking, bribery, fraud, transactions with illicit funds, and crimes against the environment. ${ }^{115}$ According to the Mexican Federal Criminal Code, a judge is able to fine a corporation up to approximately $\$ 4,100,000$ and suspend or dissolve the corporation. 116 These reforms are part of Mexico's General Law of the National Anti-Corrupt System, which includes policies and procedures for the prevention, detention, and punishment of corrupt acts and administrative offenses. ${ }^{117}$

Despite the law's recent enactment, it is clear that the new reforms are abiding by the notion of corporate cooperation with the government by enacting proper compliance programs. Similar to the leniency agreements in Chile, there are leniency mechanisms established in Mexico's General Law of Administrative Liabilities. Under this law, corporate entities can receive credit if they choose to cooperate in reporting misconduct to the government after conducting an investigation. ${ }^{118}$ Any sanctions that an individual may receive can also be reduced by about 50-70 percent if they cooperate with authorities. ${ }^{119}$

Because of the backdrop under which these reforms were made in Mexico, the case law on corporate criminal liability is in its early stages of development.120 Thus, it is important that as cases are brought, Mexico's authorities use DPAs or leniency agreements to ensure a move toward a stricter regulatory environment.

When the Mexican government prosecutes a corporate entity, deferred prosecution-type agreements should be heavily enforced over non-prosecution-type agreements. When Mexico's current president, Enrique Peña Nieto, ran his presidential campaign, he promised to combat corruption in Mexico. ${ }^{121}$ Corruption continues to be a risk for companies operating in Mexico. ${ }^{122}$

The fact that NPAs do not require formal filing in court may result

115. Patiño, supra note 113.

116. See Daniel Maldonado Alcantara, Humberto Morales Barron \& Alberto Lascurain, Anti-Corruption 2018: Mexico, LATIN LAW., http://atinlawyer.com/jurisdiction/1004770/ mexico (last verified Oct. 5, 2017).

117. Id.

118. Matteson Ellis, Important Aspects of Mexico's National Anti-Corruption System, Part 2, CORP. COMPLIANCE INSIGHTS (Apr.17, 2017), http://www.corporatecompliance insights.com/important-aspects-of-mexicos-national-anti-corruption-system-part-2/.

119. See id.

120. Alcantara et al., supra note 117 .

121. See Mauricio Torres, Las 7 Reformas Que Propone Pena Nienot Para Mexico, ExPANSION EN ALIANZA CON CNN (Aug. 27, 2012, 1:01 PM) (Mex.), http://expansion.mx/nacional/2012/08/27/una-

reforma-fiscal-integral.

122. See Mexico Corruption Report, GAN Business ANTI-CorRuPtion PortaL, http://www.business-anti-corruption.com/country-profiles/mexico. 
in a continued negative public perception of the Mexican judiciary, which may decrease the level of deterrence NPAs could offer. A 2016 Global Imputy Index study for Mexico found that "less that 1\% of crimes in Mexico are punished." 123 Because of the high number of businesses involved in corruption, NPAs that allow many of these companies to get away with having their charges dropped after compliance may not really deter corporate entities from further criminal activity.

The vast majority of the Mexican population perceives the courts to be corrupt and subject to political interference at both state and local levels. ${ }^{124}$ Because of the public perception in Mexico, non-prosecutiontype agreements could likely be perceived as companies using these agreements to buy off enforcement officials and agencies. This may result in the Mexican population losing faith in the legitimacy of their judiciary system. ${ }^{125}$ In addition, business executives believe that the Mexican judiciary system is ineffective in settling challenges to regulations. ${ }^{126}$ Due to the lengthy delays of judiciary procedures, long periods of time may pass before charges are filed or take effect. Therefore, there is a strong possibility that business executives will continue their corrupt practices.

There are also limits on market competitiveness because the cost of doing business in Mexico is higher than in neighboring countries. ${ }^{127}$ Because the nature of a corporation includes maximizing profits, by conducting a cost benefit analysis, some corporations can determine whether to commit a crime "depending on the difference between the expected benefits of the offense to the corporation from the offense and the expected cost of the offense." 128 Large businesses making large profits might determine that any criminal penalties that may be imposed might be worth paying if it allows them to continue their unlawful misconduct. Small companies likely have one primary place of business and do not make substantial profits. Thus, they will be highly incentivized to implement procedures and compliance programs in accordance with the law. This does not mean that large corporations will not comply, as criminal liability falls equally, regardless of the size of a corporate entity. The fact that DPAs include restitution and other remedial relief (not just monetary penalties), coupled with the

123. JuAn Antonto Le Clerce Ortega \& Gerado Rodriguez SÁnchez, Global IMPUNITY INDEX MEXICO IGI-MEX 2016, at 14 (2016), translated in http://www.udlap. $\mathrm{mx} /$ igimex/assets/files/igimex2016_ENG.pdf.

124. See Mexico Corruption Report, supra note 123.

125. See id.

126. See id.

127. See id.

128. John T. Byam, The Economic Inefficiency of Corporate Criminal Liability, $73 \mathrm{~J}$. CRIm. L. Criminology 582, 586-87 (1982). 
acknowledgement of wrongdoing, can deter large corporations from unlawful actions out of fear of being driven out of business and a fear of the shame and stigma that is likely to come from the community once the wrongful action has been brought to light.

There are many reasons why DPAs (or deferred prosecution-type agreements) can be beneficial to the Mexican government. Under Article $11 \mathrm{bis}$, it is important that companies have certain individuals who monitor the corporation's conduct. ${ }^{129}$ For this to be effective, companies need compliance practices in place and effective guidelines. The leniency mechanisms as part of the General Law of Administrative Liabilities is a great start for the Mexican government. Adopting deferred prosecutiontype agreements can possibly strengthen the government's enforcement efforts by having corporations at the very least enact compliance and reporting systems.

\section{Possible Global Convergence Around Norms}

\section{A. With Respect to substantive issues of corporate criminal liability}

Mexico's case law will develop as the government begins to enforce its amended laws in prosecuting corporations. Mexico is not the only Latin American country that has recently amended its laws to reflect the importance of the corporate criminal liability doctrine. In February 2016, Colombia enacted Law 1778, the Transnational Corruption Act, which allows the government to prosecute corporations for bribes paid abroad in an effort to strengthen its enforcement regime and curve corruption. ${ }^{130}$ Mexico and Columbia now join many Latin American countries that impose corporate criminal liability. ${ }^{131}$

I propose that the more countries amend their laws to punish corporations for criminal wrongdoings, the more likely it is that a convergence toward an implied understanding of the benefits of this doctrine will arise. As shown from the previous cases, the doctrine provides a bigger deterrence mechanism when the government punishes both the individual and the corporation. ${ }^{132}$ Punishing individuals in

129. See Alcantra et al., supra note 117.

130. Matteson Ellis, The "TCA": Colombia's New Foreign Bribery Law, FCPAMERICAS BLOG (April 22, 2016), http:/ffcpamericas.com/english/anti-corruption-compliance/tcacolombias-foreign-bribery-law/.

131. For the exact criminal laws in various countries, including other Latin American countries not discussed, see Corporate Liability for Corruption Offences in Latin America, ORGANISATION FOR ECONOMIC CO-OPERATION AND DEVELOPMENT, http://www. oas.org/juridico/pdfs/enc_compilation.pdf.

132. See Attorney General Jeff Sessions, Remarks at Ethics and Compliance Initiative Annual Conference (Apr. 24. 2017) (transcript available at https:/www.justice.gov/opa 
some capacity ensures they comply with all laws and regulations, and by holding the corporate entity vicariously liable, the corporation is kept from merely terminating the guilty individuals to avoid responsibility. ${ }^{133}$ If there were no vicarious liability imposed, individuals would be punished with harsher sanctions or penalties. ${ }^{134}$ This would increase the possibility of punishing innocent individuals merely because the finger has to be pointed at someone "culpable." This presents another strong justification for why effective deterrence requires sanctions aimed at the corporation as a whole. ${ }^{135}$ In a world of increasing global business, many corporations have grown and established themselves on a national level, with high stakes in the economic and industrial sectors of the world. ${ }^{136}$

Many Latin American countries now have laws in place that account for corporate wrongdoings. Latin America is just one part of the world. Many other foreign jurisdictions also have some form of the corporate criminal liability doctrine in their criminal statutes.

The approach in other foreign jurisdictions reflect a convergence in the norms around the importance of the substantive law of this doctrine in a variety of industries. In Canada, for instance, the Canadian Criminal Code imposes a duty on both individuals and organizations to maintain health and safety regulations for the well-being of individuals in the workplace. ${ }^{137}$ Because most penal offenses under Canadian law are regulatory offenses, the term "organization" is defined broadly to include liability imposed on corporations. ${ }^{138}$ Similarly, many jurisdictions in Europe impose regulatory sanctions for the criminal acts of a corporate entity's employees. ${ }^{139}$ For example, the United Kingdom's Corporate Manslaughter and Corporate Homicide Act of 2007 allows a corporation to be found guilty when the corporation's activities show a gross breach in the duty of care that results in an individual's death. ${ }^{140}$

Many countries that impose corporate criminal liability have laws that are similar to those in the United States. Finish law is very similar to U.S. law in which criminal liability is imposed when management

/speech/attorney-general-jeff-sessions-delivers-remarks-ethics-and-compliance-initiativeannual).

133. See Ball \& Bolia, supra note 2, at 236 .

134. See id.

135. See id.

136. Tanvi Sharma, Corporate Criminal Liability in the Contemporary World, THE WORLD J. JURISTIC POLITY 1 (2016).

137. See Norm Keith \& Graham Walsh, International Corporate Criminal Liability, 8 WORLD Focus 1, at 19.

138. Id.

139. See id.

140. See id. 
carries out criminal acts for the benefit of the corporation. ${ }^{141}$ Austria and Belgium take the same approach in that the wrongful act must be done for the benefit of the corporation. ${ }^{142}$ While Japan has no corporate criminal liability doctrine to date, Japanese law will impose corporate liability when an agent or an employee commits a crime under the negligent supervision of the corporation. ${ }^{143}$ Thus, while Japanese law has not adopted or enacted an official corporate criminal liability doctrine, prosecuting a corporation is still possible.

While the countries I have discussed represent only a fraction of the world, there seems to be a possible global convergence toward this doctrine. Amendments in the law show how the international regulatory community is moving toward stricter regulation. ${ }^{144}$ On March 15-16, 2018, a Global Forum on Corporate Criminal Liability was held in Konigstein, Germany, to discuss pressing issues regarding corporate criminal litigation. ${ }^{145}$ The Forum brought together leaders in the field from all over the world to share their perspectives on this area of law and discuss issues regarding global enforcement and investigation. ${ }^{146}$ The forum provides an environment to discuss complex global issues, offer differing perspectives, and develop solutions to these issues that work in a variety of jurisdictions. ${ }^{147}$

\section{B. Toward a Compliance-Oriented Approach}

With globalization and the rapid expansion of information technologies allowing companies to gain a large amount of control and influence across the globe, ${ }^{148}$ it is important that there is a push towards compliance-oriented enforcement. In 2016, there were 132 organizations that were sentenced in the United States, and according to the U.S. Sentencing Commission, only 2.1 percent of those organizations had effective compliance programs in place. ${ }^{149}$

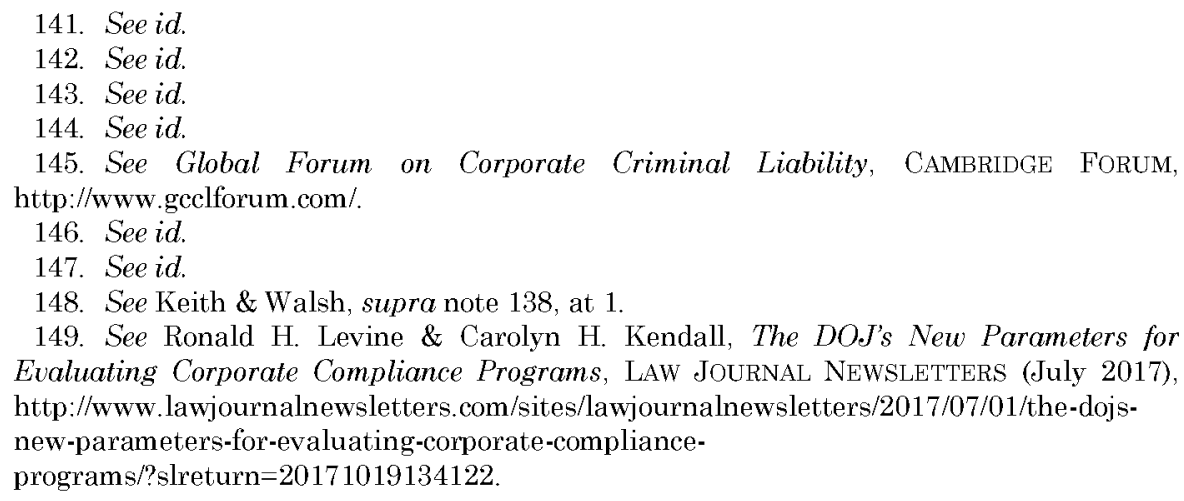
Evaluating Corporate Compliance Programs, LAW Journal Newsletters (July 2017), http://www.lawjournalnewsletters.com/sites/lawjournalnewsletters/2017/07/01/the-dojsnew-parameters-for-evaluating-corporate-complianceprograms/?slreturn $=20171019134122$. 
More recently, the Department of Justice's Fraud Division has published the Evaluation of Corporate Compliance Programs, which provides a series of guidelines that it uses when it evaluates a corporation's compliance program. ${ }^{150}$ These guidelines set out eleven main section topics, each with its own set of questions that the DOJ asks when evaluating the effectiveness of a compliance program. ${ }^{151}$ The DOJ notes that evaluations are conducted on a case-by-case basis to account for a corporation's inherent differences, which are taken into account in the way the questions are subdivided. ${ }^{152}$ These guidelines are strong indicators of the importance of a compliance-orientated approach since having an effective compliance program is one of the factors that prosecutors evaluate in determining whether they prosecute a corporation. ${ }^{153}$ Given the discretion that the U.S. Attorney Manual gives prosecutors, the New Compliance Guidelines Program evaluation serves as a proper supplement. The parameters of the guidelines include "a comprehensive overview of compliance program methodologies, structure and implementation, as well as how the program is empowered, resourced, and monitored in practice at different organizational levels." 154 With the DOJ's new compliance program in place, it is important that those at the forefront of corporations become familiar with these guidelines to ensure their compliance programs meet standards.

In cases regarding the Foreign Corrupt Practices Act (FCPA), there also seems to be a recognition of the importance of a complianceoriented approach in imposing corporate criminal liability. Former Acting Assistant Attorney General Kenneth Blanco discussed the importance of cooperation from foreign law enforcement in FCPA investigations. ${ }^{155}$ The FCPA guidelines will be directly applicable to

150. See Evaluation of Corporate Compliance Programs, U.S. DEPARTMENT OF JUSTICE, https://Www.justice.gov/criminal-fraud/page/file/937501/download.

151. See id.

152. See Levine \& Kendall, supra note 150.

153. See Christopher D. Carusone, Reducing the Risk of Corporate Criminal Liability, Cohen Segla Palla Greenhall \& Furman PC: A Closer look: Internal INVESTIGATIONS (March 21, 2017), https://www.investigationslawblog.com/2017/03/ reducing-risk-corporate-criminal-liability/; See also U.S. ATTORNEY'S MANUAL. § 928.300(5) ("In conducting an investigation, determining whether to bring charges, and negotiating plea or other agreements, prosecutors should consider the following factors in reaching a decision as to the proper treatment of a corporate target ... the existence and effectiveness of the corporation's pre-existing compliance program[.]").

154. See Levine \& Kendall, supra note 150.

155. Buckley Sandler, Justice Department Official Stresses International Cooperation in FCPA Enforcement, BUCKLEY SANDLER (July 28, 2017), https://buckleysandler.com/blog/ 2017-07-28/justice-department-official-stresses-international-cooperation-fcpa-

enforcement ("As transnational crime continues to grow in scope and complexity, we 
companies operating in foreign jurisdictions since companies now operate on a global level. ${ }^{156}$

The United States Commodity Future Trading Commission (CFTC) now also uses deferred prosecution agreements and non-prosecution agreements in their effort to move toward a compliance-oriented approach. In January 2017, the CFTC granted its first NPA against Citigroup Global Markets Inc., recognizing that NPAs incentivize corporations to comply and cooperate in government investigations. ${ }^{157}$ The CFTC Enforcement Division stated that it will continue to use DPAs and NPAs as they are "powerful tool[s] to reward extraordinary cooperation ... while providing individuals and organizations strong incentives to promptly accept responsibility for their wrongdoing." 158

The shift toward a compliance-oriented approach in corporate criminal liability is also occurring in various foreign jurisdictions in multiple contexts. In the context of corruption in Latin America, I have discussed how leniency agreements in Chile ${ }^{159}$ and the leniency mechanisms as part of the General Law of Administrative Liabilities in Mexico $^{160}$ are examples of the shift toward a culture of cooperation and compliance in Latin America. In the United Kingdom, the U.K. Compliance Guide outlines a compliance system for proper procedures to curve corporate liability under the U.K. Bribery Act. ${ }^{161}$ In addition, the U.K. conduct regulator issued a series of papers that show the United Kingdom is striving to establish and maintain a "culture of conduct" through incentives for regulatory compliance in the financial-

increasingly find ourselves looking across the globe to collect evidence and identify witnesses necessary to build cases, requiring greater and closer collaboration with out foreign counterparts. As a result, we find ourselves relying more and more on the use of the various mechanisms of international cooperation with out foreign partners that permit for evidence exchange, fugitive apprehension, and asset recover.").

156. See Elisabeth Roscher \& Kine Bjelke Christophersen, Corporate Criminal Liability; The Impact of an Effective Compliance Program, WIKBORG REIN (June 19, 2018), https://www.wr.no/en/news/news/corporate-criminal-liability-the-impact-of-an-effectivecompliance-program/.

157. See Aitan Goelman, CFTC Non-Pros Agreements with Citibank Traders Reflects Implementation of New Cooperation Advisories, N.Y.U. PROGRAM ON CORPORATE COMPLIANCE AND ENFORCEMENT https:/wp.nyu.edu/compliance_enforcement/2017/07/13/ cftc-non-pros-agreements-with-citibank-traders-reflects-implementation-of-new-

cooperation-advisories/\#more-2077.

158. See id.

159. See Ellis, supra note 104.

160. See Ellis, supra note 119.

161. See UK Compliance Guide, GAN Business ANTI-Corruption Portal: Complance GuidEs, http://www.business-anti-corruption.com/compliance-quick-guides/united kingdom. 
service industry. ${ }^{162}$

In the environmental regulation context, Australian officials have proposed numerous regulations including environment improvement plants, operator and pollution risk assessments, and loaded based licensing schemes to ensure compliance. ${ }^{163}$ Finally, similar to the recently enacted New Compliance Guidelines Program by the DOJ Fraud Division, the US-China Business Council has published a Best Practices of Managing Compliance in China to ensure companies enact and manage compliance programs. ${ }^{164}$ With various jurisdictions enacting compliance programs and guides in various industries, the goals of criminal law-deterrence and punishment ${ }^{165}$ for corporate wrongdoings-are being achieved in the United States and numerous foreign jurisdictions.

\section{CONCLUSION}

Recent regulations seem to indicate a possible global convergence around norms with respect to both the substantive issues that affect corporate criminal liability and the importance of a compliance-oriented approach to the problem surrounding the doctrine. The laws enacted in Latin America suggest that these countries recognize the importance of the doctrine in ensuring corporate entities are punished for violations of the law. The recent laws enacted in these jurisdictions suggest a shift toward regulation of corporate actions and ensures their compliance with the government laws and regulations. My brief overview of the laws imposing corporate criminal liability in other foreign jurisdictions seems to suggest that other countries are also moving toward a compliance-oriented approach

It is important that corporations enact proper compliance programs to deter future criminal acts and misconduct. In the United States, the DOJ has set out guidelines and evaluation standards to ensure that compliance programs are effective at deterring crime and do not simply exist on paper. The continued use of DPAs and NPAs will likely

162. See Steve Blackbourn, Embedding the Right Culture and Incentivizing Co-operative Compliance in the UK, WOLTERS KLUWER (Feb. 1, 2017), http://www.wolterskluwerfs .com/article/embedding-the-right-culture-and-incentivising-co-operative-compliance-inthe-uk. aspx.

163. See Neil Gunningham, COMPliance ENFORCEMENT AND InNOvation 1-3, https://www.oecd.org/env/outreach/33947825.pdf.

164. For the full guide, see The U.S.-China Business Council, Best Practices for MANAGING COMPLIANCE IN CHINA (2013), https:/www.uschina.org/sites/default/files USCBC\%20Compliance\%20Report\%202013_0.pdf.

165. See Joshua Dressler \& Stephen P. Garvey, Criminal LaW Cases and MATERIALS 38 (7th ed. 2016). 
continue to be an effective tool for prosecuting corporate entities. Comments from the current administration suggest that the use of these agreements will expand and be used in other contexts apart from common corporate crimes, while ensuring that the result is equitable to all parties involved. Because many companies have expanded and operate in multiple jurisdictions, it is extremely important to ensure their compliance with the law and create a sense of harmony in the increasingly globalized business world we live in today. 
